\title{
Laboratory research of vibration impact parameters on the coal seam through host rocks
}

\author{
Oleksandr Petukh ${ }^{1, *}$, Kostiantyn Sofiiskyi ${ }^{1}$, and Dmytro Zhytlonok ${ }^{1}$ \\ ${ }^{1}$ Institute of Geotechnical Mechanics named by N. Poljakov of National Academy of Sciences of \\ Ukraine, 49005, Dnipro, Simferopolska Str., 2a, Ukraine
}

\begin{abstract}
On the basis of mechanized roof supports, the hydraulic systems of vibrators operating as compact vibrators for controlling the condition of the coal and rock mass through host rocks are selected and refined. Bench testing of vibrator systems operating in continuous and pulsed modes with automatic control were held. The basic parameters of the systems of vibrators are established, and the fundamental possibility of their work in the working face of gas-dangerous mines was proved.
\end{abstract}

\section{Introduction}

Currently, vibratory machines and mechanisms are widely used in almost all industries and national economy. Their widespread use is due to the specific impact of vibrations on the various properties of solids, dry and liquids material.

The introduction of vibrotechnics in the industry assists to the intensification of technological processes increases the economic efficiency of enterprises, increases labor productivity. It also greatly simplifies and facilitates the automation of many technological processes, creates convenience when moving gassing and dusty materials, simplifies devices for intermediate loading and unloading coals, allows combining technological processes, etc.

For the coal industry is relevant when the mining complex was combined and safe. Namely, it included operation to reduce the outbreak of reduce fortresses bottomhole zone coalbed seam, on the management of the hard-to-fall roof, including outburst hazardous, enclosing rocks, that is make the coal mining process uniform and safe. Thus, several schemes of vibrator systems for vibration impact on the coal-rock massive were considered which took into account the possibility of using hydraulic equipment commercially produced by the machine-building industry of Ukraine.

Of all the systems considered, the most appropriate were selected as compact hydraulic machines as follows:

1) systems of hydraulic vibrators operating in continuous vibration mode;

2) systems of hydraulic vibrators operating in pulsed mode.

For their use in working gas mines it is necessary to establish the fundamental

\footnotetext{
*Corresponding author: igtmdep16@gmail.com
} 
possibility of the operation of such systems as compact vibrating machines to control the condition of the coal and rock massive.

Therefore, the aim of the work is to conduct bench tests of the systems of hydraulic vibrators and the establishment of their main parameters for impact the coal-rock massive through host rocks.

\section{Methods}

When conducting research on vibrator systems on the stand, the following main tasks were solved:

1) verification of the performance of the proposed designs of the systems of vibrators;

2) the study of the characteristics of the systems of vibrators (the frequency of oscillations of the rods of hydraulic props, the time of the pressure in the piston cavity, the time of unloading, the shape and amplitude of the oscillations, etc.);

3 ) the accumulation of experience with systems of hydraulic vibrators with regard to their use in gas mines.

Studies of the proposed systems of vibrators [1] were carried out on a laboratory stand (Fig. 1), which consisted of the upper support 1, racks 2 and the base 3 . The base and upper supports were made of I-beams \#33 and the racks of I-beams \#20.

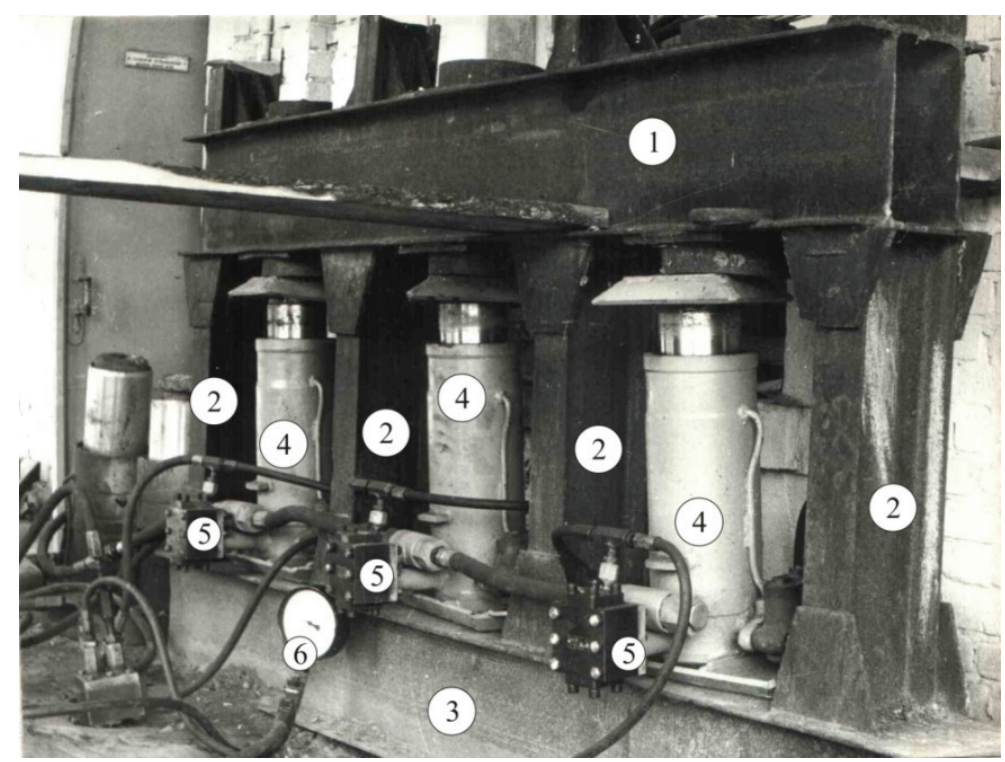

Fig. 1. Laboratory stand for testing vibrator systems: 1 - upper support; 2 - stand; 3 - lower support; 4 - hydraulic racks; 5 - tensometric pressure sensors; 6 - manometer.

The change in pressure in the piston cavities of the hydraulic racks 4 was recorded using tensometric pressure sensors 5. Measuring equipment was connected to the sensors: a tensometer amplifier and a light beam oscilloscope. For visual observation, as well as for the calibration of strain gauges, a tensometer 6 was used.

Research of the characteristics of the systems of vibrators were carried out in the following order:

1) using a crane beam, were installed hydraulic props on the stand;

2) the power supply of the vibrator systems was installed;

3) connected instrumentation;

4) registration of characteristics of systems of vibrators; 
5) dismantling of vibrator systems;

6) processing of measurement results.

The research of the systems characteristics of vibrators was carried out in continuous vibration and pulsed modes of operation at different initial pressures, volumes of piston cavities, rotational frequencies of the pneumatic engine, etc. The evaluation of the measurement results made it possible to establish that the true value of the measured values is in the required interval.

\section{Results and discussion}

The dependence of the change in the pressure amplitude in a hydraulic prop on the oscillation frequency of the rod and its variable volumes of piston cavities in the continuous vibration mode was determined $[2,3]$.

At the beginning, the tests were carried out on three hydraulic prop, and after the breakdown of one prop - on two props. The data obtained during waveform processing are presented in tables 1 and 2. On the basis of their built graphs of pressure changes in the piston cavities of hydraulic props on the oscillation frequency under different initial conditions (Fig. 2, 3).

Table 1. The change in pressure in the piston cavities of three hydraulic props depending on the initial pressure, initial volume and frequency of oscillation of the piston.

\begin{tabular}{|c|c|c|c|c|c|}
\hline \multirow{2}{*}{$\begin{array}{c}\text { Piston } \\
\text { oscillation } \\
\text { frequency, } \\
\quad f, \mathrm{~Hz}\end{array}$} & \multicolumn{2}{|c|}{ Hydraulic props pressure, $\mathrm{MPa}$} & \multirow{2}{*}{$\begin{array}{l}\text { Pressure } \\
\text { change in } \\
\text { hydraulic } \\
\text { props, } \\
\triangle P, \mathrm{MPa}\end{array}$} & \multicolumn{2}{|c|}{ Initial conditions } \\
\hline & $\min$ & $\max$ & & $\begin{array}{c}\text { Props } \\
\text { pressure, } \\
P_{0}, \mathrm{MPa}\end{array}$ & $\begin{array}{l}\text { The volume of } \\
\text { the piston cavity } \\
\text { prop, } V_{0}, \mathrm{~m}^{3}\end{array}$ \\
\hline 1.20 & 2.69 & 6.85 & 4.16 & 8.00 & 0.00095 \\
\hline 1.20 & 2.34 & 7.12 & 4.78 & 8.00 & 0.00095 \\
\hline 1.20 & 2.15 & 7.93 & 5.78 & 8.00 & 0.00095 \\
\hline 1.50 & 2.58 & 6.03 & 3.45 & 8.00 & 0.00095 \\
\hline 1.50 & 2.28 & 6.18 & 3.90 & 8.00 & 0.00095 \\
\hline 1.50 & 2.03 & 7.12 & 5.09 & 8.00 & 0.00095 \\
\hline 2.00 & 2.83 & 5.64 & 2.81 & 8.00 & 0.00095 \\
\hline 2.00 & 2.58 & 5.98 & 3.40 & 8.00 & 0.00095 \\
\hline 2.00 & 2.03 & 6.45 & 4.42 & 8.00 & 0.00095 \\
\hline 3.00 & 2.67 & 4.80 & 2.13 & 8.00 & 0.00095 \\
\hline 3.00 & 2.28 & 4.93 & 2.65 & 8.00 & 0.00095 \\
\hline 3.00 & 2.01 & 5.76 & 3.75 & 8.00 & 0.00095 \\
\hline 3.50 & 2.49 & 4.52 & 2.03 & 8.00 & 0.00095 \\
\hline 3.50 & 2.19 & 4.61 & 2.42 & 8.00 & 0.00095 \\
\hline 3.50 & 1.64 & 5.14 & 3.50 & 8.00 & 0.00095 \\
\hline 4.00 & 2.76 & 4.48 & 1.72 & 8.00 & 0.00095 \\
\hline 4.00 & 2.33 & 4.57 & 2.24 & 8.00 & 0.00095 \\
\hline 4.00 & 1.89 & 5.10 & 3.21 & 8.00 & 0.00095 \\
\hline 4.50 & 2.39 & 4.02 & 1.63 & 8.00 & 0.00095 \\
\hline 4.50 & 2.15 & 4.28 & 2.13 & 8.00 & 0.00095 \\
\hline 4.50 & 1.84 & 4.92 & 3.08 & 8.00 & 0.00095 \\
\hline 5.50 & 2.07 & 3.65 & 1.58 & 8.00 & 0.00095 \\
\hline 5.50 & 1.95 & 3.81 & 1.86 & 8.00 & 0.00095 \\
\hline 5.50 & 2.12 & 4.89 & 2.77 & 8.00 & 0.00095 \\
\hline
\end{tabular}


Table 2. The change in pressure in the piston cavity of two hydraulic props, depending on the initial pressure, initial volume and frequency of oscillation of the piston.

\begin{tabular}{|c|c|c|c|c|c|}
\hline \multirow{2}{*}{$\begin{array}{c}\text { Piston } \\
\text { oscillation } \\
\text { frequency, } \\
f, \mathrm{~Hz}\end{array}$} & \multicolumn{2}{|c|}{$\begin{array}{c}\text { Hydraulic props pressure, } \\
P, \mathrm{MPa}\end{array}$} & \multirow{2}{*}{$\begin{array}{l}\text { Pressure } \\
\text { change in } \\
\text { hydraulic } \\
\text { props, } \Delta P, \\
\mathrm{MPa}\end{array}$} & \multicolumn{2}{|c|}{ Initial conditions } \\
\hline & $\min$ & $\max$ & & $\begin{array}{c}\text { Props } \\
\text { pressure, } \\
P_{0}, \mathrm{MPa}\end{array}$ & $\begin{array}{l}\text { The volume of the } \\
\text { piston cavity prop, } \\
\qquad V_{0}, \mathrm{~m}^{3}\end{array}$ \\
\hline 2.00 & 3.95 & 7.00 & 3.05 & 7.50 & 0.00207 \\
\hline 2.00 & 0.94 & 3.22 & 2.28 & 7.50 & 0.00207 \\
\hline 3.00 & 3.68 & 6.11 & 2.43 & 7.50 & 0.00207 \\
\hline 3.00 & 0.85 & 2.52 & 1.67 & 7.50 & 0.00207 \\
\hline 4.00 & 3.56 & 5.59 & 2.03 & 7.50 & 0.00207 \\
\hline 4.00 & 0.63 & 1.93 & 1.30 & 7.50 & 0.00207 \\
\hline 5.00 & 3.27 & 5.07 & 1.80 & 7.50 & 0.00207 \\
\hline 5.00 & 0.42 & 1.72 & 1.30 & 7.50 & 0.00207 \\
\hline 5.75 & 3.27 & 4.84 & 1.57 & 7.50 & 0.00207 \\
\hline 5.75 & 0.29 & 1.54 & 1.25 & 7.50 & 0.00207 \\
\hline 6.05 & 3.74 & 5.21 & 1.57 & 7.50 & 0.00207 \\
\hline 6.05 & 0.58 & 1.83 & 1.35 & 7.50 & 0.00207 \\
\hline 2.75 & 5.02 & 10.99 & 5.97 & 11.00 & 0.00207 \\
\hline 2.75 & 2.00 & 7.28 & 5.28 & 11.00 & 0.00207 \\
\hline 3.75 & 5.02 & 9.65 & 4.63 & 11.00 & 0.00207 \\
\hline 3.75 & 2.11 & 6.03 & 3.92 & 11.00 & 0.00207 \\
\hline 4.75 & 5.43 & 9.23 & 3.80 & 11.00 & 0.00207 \\
\hline 4.75 & 2.42 & 5.57 & 3.15 & 11.00 & 0.00207 \\
\hline 5.25 & 1.58 & 5.11 & 3.53 & 11.00 & 0.00207 \\
\hline 5.25 & 0.00 & 2.70 & 2.70 & 11.00 & 0.00207 \\
\hline 6.00 & 1.65 & 5.02 & 3.37 & 11.00 & 0.00207 \\
\hline 6.00 & 0.22 & 2.84 & 2.62 & 11.00 & 0.00207 \\
\hline 1.20 & 5.94 & 12.30 & 6.36 & 13.00 & 0.00142 \\
\hline 1.20 & 6.64 & 12.51 & 5.87 & 13.00 & 0.00142 \\
\hline 1.50 & 5.74 & 10.88 & 5.14 & 13.00 & 0.00142 \\
\hline 1.50 & 7.02 & 11.45 & 4.43 & 13.00 & 0.00142 \\
\hline 1.70 & 5.53 & 10.86 & 5.33 & 13.00 & 0.00142 \\
\hline 1.70 & 7.22 & 11.17 & 3.95 & 13.00 & 0.00142 \\
\hline 2.00 & 5.53 & 10.15 & 4.62 & 13.00 & 0.00142 \\
\hline 2.00 & 6.76 & 10.44 & 3.68 & 13.00 & 0.00142 \\
\hline 2.20 & 5.53 & 10.04 & 4.51 & 13.00 & 0.00142 \\
\hline 2.20 & 6.99 & 10.21 & 3.22 & 13.00 & 0.00142 \\
\hline 2.70 & 5.53 & 9.63 & 4.10 & 13.00 & 0.00142 \\
\hline 2.70 & 6.53 & 9.52 & 2.99 & 13.00 & 0.00142 \\
\hline 3.20 & 4.92 & 8.61 & 3.69 & 13.00 & 0.00142 \\
\hline 3.20 & 5.84 & 8.37 & 2.53 & 13.00 & 0.00142 \\
\hline
\end{tabular}

Graph analysis in Figure 2 for three hydraulic props confirms that with an increase in the oscillation frequency the change in pressure in the piston cavities of the hydraulic props decreases which corresponds to the theoretical studies carried out [4]. So, with the frequency of oscillations of the $\operatorname{rod} f=1.2 \mathrm{~Hz}$, the average value of the pressure change in 
the hydraulic props is $4.9 \mathrm{MPa}$, and at $f=5.5 \mathrm{~Hz}-2.1 \mathrm{MPa}$. The maximum oscillation frequency of the pistons of the three props was $5.5 \mathrm{~Hz}$.

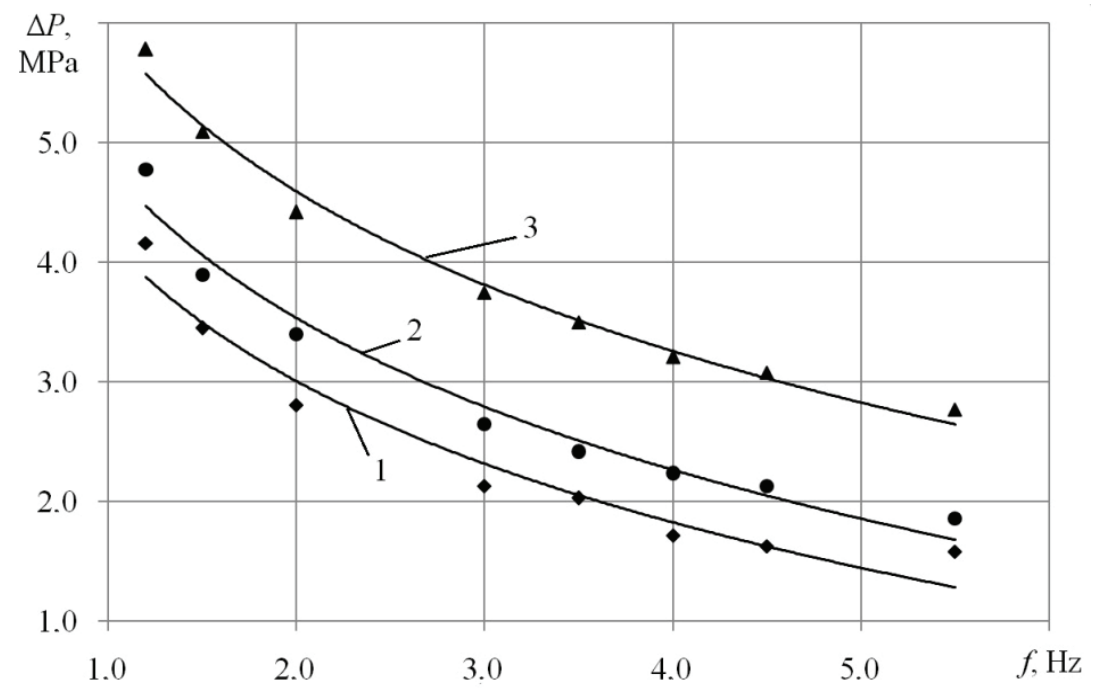

Fig. 2. Pressure change in piston cavities as a function of the oscillation frequency for three hydraulic props: 1 - hydraulic prop \#1; 2 - hydraulic prop \#2; 3 - hydraulic prop \#3.

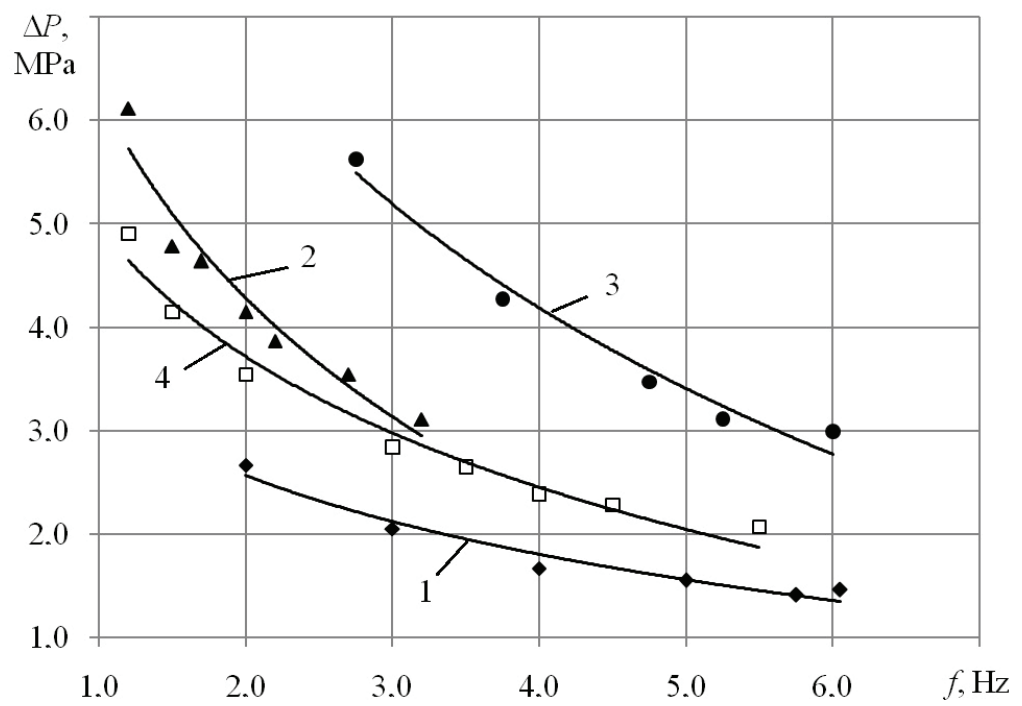

Fig. 3. Dependence of average values of pressure change in piston cavities on the oscillation frequency for two and hydraulic props under different initial conditions: 1 - two hydraulic props with $V_{0}=0.00207 \mathrm{~m}^{3}$ and $P_{0}=7.5 \mathrm{MPa} ; 2-$ two hydraulic props with $V_{0}=0.00207 \mathrm{~m}^{3}$ and $P_{0}=11.0 \mathrm{MPa}$; 3 - two hydraulic props with $V_{0}=0.00142 \mathrm{~m}^{3}$ and $P_{0}=13.0 \mathrm{MPa} ; 4$ - three hydraulic props with $V_{0}=0.00095 \mathrm{~m}^{3}$ and $P_{0}=8.0 \mathrm{MPa}$.

The graph is described by the following logarithmic equations: for hydraulic prop \#1, $P(f)=-1.92 \ln (f)+5.928$ with accuracy of approximation $R^{2}=0.99$; for a hydraulic prop \#2, $P(f)=-1.83 \ln (f)+4.804$ with accuracy of approximation $R^{2}=0.97$; for a hydraulic prop $\# 3, P(f)=-1.7 \ln (f)+4.189$ with accuracy of approximation $R^{2}=0.96$. 
The graphs of the pressure change in the hydroelectric piston cavities for the average values of the experimental studies results are shown in Figure 3.

Analysis of the graphs shows that the character of the established dependencies is similar to that obtained for a system of three hydraulic props. When reducing the flow area in the drain line is observed shift of the reference point of the pressure amplitude in the direction of its increase.

It was determined that with increasing pressure, the impact force generated by the vibrator system increases, the maximum value of which was at $P=13 \mathrm{MPa}$ for a system of two hydraulic props $\sim 710 \mathrm{kN}$ and at $P=8.0 \mathrm{MPa}$ for a system of vibrators from three hydraulic props $\sim 600 \mathrm{kN}$.

The graphs are described by the following logarithmic equations:

- graph $1 P(f)=-1.1 \ln (f)+3.331$ with accuracy of approximation $R^{2}=0.96$;

- graph $2 P(f)=-2,82 \ln (f)+6.237$ with accuracy of approximation $R^{2}=0.94$;

- graph $3 P(f)=-3.49 \ln (f)+9.024$ with accuracy of approximation $R^{2}=0.98$;

- graph $4 P(f)=-1.81 \ln (f)+4.974$ with accuracy of approximation $R^{2}=0.98$.

When analyzing the oscillograms, the synchronicity and phase shift of forced oscillations of the pistons of hydraulic props are established. The phase shift with increasing frequency of oscillation of the pistons increases from $\varphi=3^{\circ}$ at $f=1 \mathrm{~Hz}$ to $\varphi=26^{\circ}$ at $f=6.5 \mathrm{~Hz}$. The phase shift is influenced by the difference in pressure losses on the resistance of pipelines after the hydraulic control valve spool.

After testing the system of vibrators in continuous mode, the system was tested to operate in a pulsed mode. Initially, tests were conducted with a manual control system. At the same time, frequency-amplitude characteristics, time of discharge of fluid pressure were obtained, the synchronous operation of hydraulic props was determined.

In processing the oscillograms of pressure changes in the piston cavities of hydraulic props (Table 3) and a graph of pressure change versus time is presented (Fig. 4).

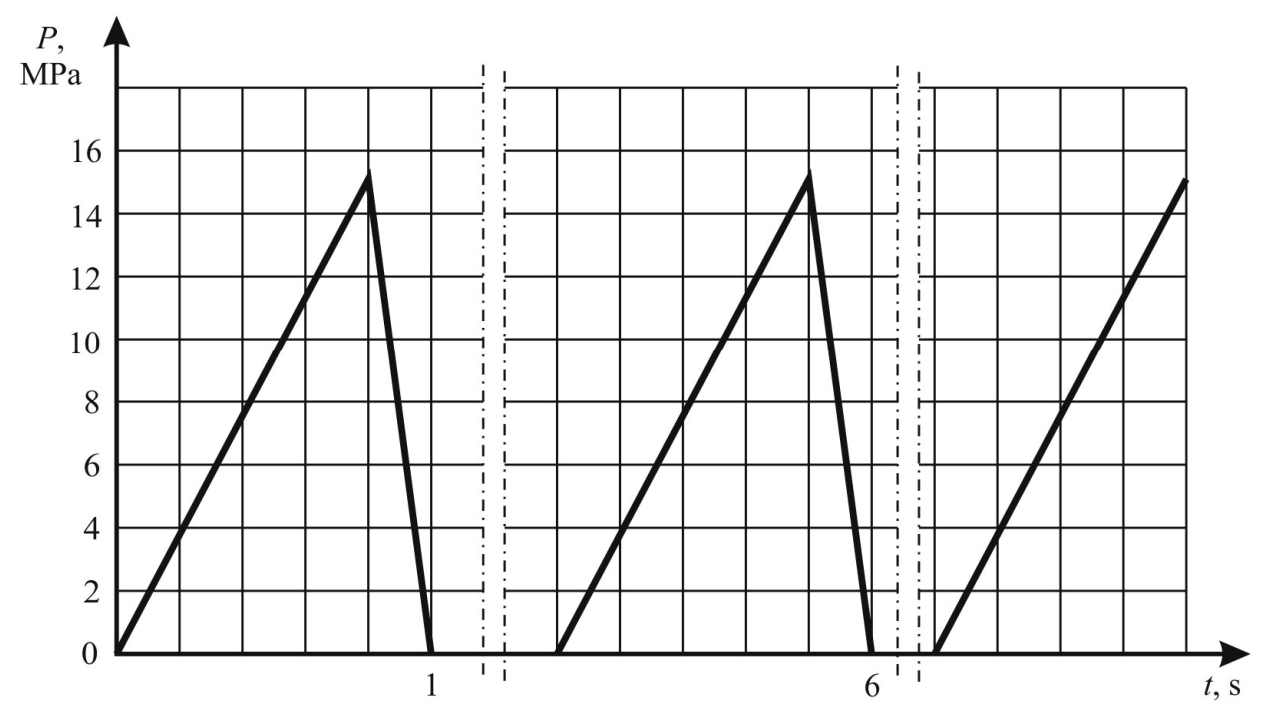

Fig. 4. The dependence of the pressure change in the piston cavities hydraulic props from time.

Analyzing the dependence obtained shows that the maximum amplitude of pressure oscillations is $15 \mathrm{MPa}$, the rise time of the pulse from zero to a maximum is 7-9 s, and the fall time is $0.10-0.15 \mathrm{~s}$. The minimum pulse repetition period is $15-20 \mathrm{~s}$. Hence, the pulse repetition rate is $f=0.06 \mathrm{~Hz}$. The pulse shape is triangular. 
Table 3. The change in pressure in the piston cavity hydraulic props depending on time.

\begin{tabular}{|c|c|}
\hline $\begin{array}{c}\text { Pressure change in hydraulic prop } \\
\Delta P, \mathrm{MPa}\end{array}$ & $\begin{array}{c}\text { Pressure recession time in hydraulic } \\
\text { prop, } t, \mathrm{~s}\end{array}$ \\
\hline 18.50 & 0.18 \\
\hline 12.00 & 0.12 \\
\hline 12.00 & 0.20 \\
\hline 12.00 & 0.13 \\
\hline 19.00 & 0.20 \\
\hline 12.00 & 0.18 \\
\hline 18.50 & 0.20 \\
\hline 11.50 & 0.11 \\
\hline 19.00 & 0.22 \\
\hline 11.00 & 0.15 \\
\hline 19.50 & 0.21 \\
\hline 12.50 & 0.13 \\
\hline 18.00 & 0.17 \\
\hline 13.00 & 0.14 \\
\hline 19.70 & 0.21 \\
\hline 13.50 & 0.15 \\
\hline 20.00 & 0.19 \\
\hline 14.00 & 0.15 \\
\hline 18.50 & 0.20 \\
\hline 11.00 & 0.10 \\
\hline & \\
\hline
\end{tabular}

In analyzing oscillograms, which were obtained by testing a system of vibrators from three poles, they were synchronized at a pulse repetition rate of $f=0.05 \mathrm{~Hz}$. The phase shift of the forced oscillations of the pistons of the hydraulic props was $\varphi=5^{\circ}$. This is influenced by the difference between the efforts of the spring action of the main valves of the hydraulic lock.

The maximum force of impact, which is created by a system of vibrators from three hydraulic legs, was $900 \mathrm{kN}$. During the testing of significant problems in the system of vibrators did not occur. This indicates a high system reliability.

The characteristics of the vibrator system operation in a pulsed mode with automatic control on the experimental equipment were determined.

The data obtained are identical to the characteristics of the operation of the vibrator system in a pulsed mode with manual control. The pulse repetition period was 15-20 s.

Measurement of sound level, vibration acceleration and vibration velocity was carried out by the noise and vibration meter VSHV-003. The results shown in tables 4 and 5. Its showed that the proposed vibrohydraulic device meets the safety requirements (does not exceed the allowable, for vibration acceleration $-12 \mathrm{~m} / \mathrm{s}^{2}$, for vibration velocity $-1.4 \mathrm{~m} / \mathrm{s}$ ), workable and can be used as a means of influence to control the state of a coal-rock massive [5].

The determination of the oscillation frequency of the piston rod was carried out according to the data obtained during experimental tests of oscillograms. Frequency determination was performed for each value (Table 1-3).

Confidence probability $\alpha=0.90$, which is sufficient for mechanical tests.

The measurement of pressure in the piston cavities of the hydraulic props was carried out with an manometer MT, accuracy class $1.5 \%$ of the final measurement scale:

$$
\eta=40 \cdot 0.015=0.6 \mathrm{MPa} \text {. }
$$


Table 4. Dependence of the noise level on the oil station pressure.

\begin{tabular}{|c|c|c|c|c|c|}
\hline \multirow{3}{*}{$\begin{array}{c}\text { Oil station } \\
\text { pressure, } \mathrm{MPa}\end{array}$} & \multicolumn{4}{|c|}{ Dynamic interval } & \multirow{3}{*}{$\begin{array}{c}\text { Frequency } \\
\text { interval, } \\
\mathrm{Hz}\end{array}$} \\
\hline & \multicolumn{4}{|c|}{ lower limit } & \\
\hline & $A$ & $B$ & $C$ & Line & \\
\hline 8 & 25 & 30 & 30 & 35 & 69 \\
\hline 9 & 27 & 32 & 33 & 38 & 72 \\
\hline 10 & 28 & 35 & 35 & 40 & 74 \\
\hline 11 & 30 & 37 & 38 & 43 & 75 \\
\hline 12 & 32 & 39 & 40 & 45 & 76 \\
\hline 13 & 35 & 43 & 42 & 48 & 80 \\
\hline 14 & 40 & 46 & 45 & 52 & 85 \\
\hline 15 & 44 & 49 & 48 & 55 & 90 \\
\hline
\end{tabular}

Table 5. Dependence of vibration acceleration, vibration velocity on the oil station pressure.

\begin{tabular}{|c|c|c|}
\hline Oil station pressure, & Vibration acceleration, $\mathrm{m} / \mathrm{s}^{2}$ & Vibration velocity, $\mathrm{m} / \mathrm{s}$ \\
\hline 8.0 & $5.0 \cdot 10^{-2}$ & 0.10 \\
\hline 9.0 & $6.5 \cdot 10^{-2}$ & 0.13 \\
\hline 10.0 & $7.8 \cdot 10^{-2}$ & 0.18 \\
\hline 11.0 & $8.9 \cdot 10^{-2}$ & 0.21 \\
\hline 12.0 & $9.8 \cdot 10^{-2}$ & 0.26 \\
\hline 13.0 & $10.6 \cdot 10^{-2}$ & 0.33 \\
\hline 14.0 & $10.8 \cdot 10^{-2}$ & 0.38 \\
\hline 15.0 & $11.2 \cdot 10^{-2}$ & 0.45 \\
\hline
\end{tabular}

The probability of a deviation in the assumption that deviations of the instrument's readings obey the normal law is determined by the formula:

$$
\varphi=\frac{0.477}{\eta}=0.8 \mathrm{MPa} \text {. }
$$

and the probability of finding deviations in the interval $\pm \varphi$ is $50 \%$.

The standard deviation $\tau$ of the instrument readings is calculated by the formula:

$$
\tau=\frac{0.707}{\eta}=1.2 \mathrm{MPa}
$$

In this case, the probability that the deviations will be within the allowable interval is $68.2 \%(\delta=6.0 \%)$.

Thus, $68.2 \%$ of all counts with a calibrated value of $20 \mathrm{MPa}$ are in the interval from 18.8 to $21.2 \mathrm{MPa}$, and half of all counts are between 19.2 and $20.8 \mathrm{MPa}$.

The evaluation of the measurement results allows us to conclude that the true value of the measured values is in the required interval.

\section{Conclusions}

1. The principal possibility of using hydraulic systems as compact hydraulic machines has been established for controlling the condition of the coal and rock massif, moving the reference pressure zone from the bottom of the clearing generation and controlling the rock pressure of a hard-to-reach roof. 
2. The basic parameters of the vibration systems operating in continuous and pulsed modes with manual and automatic control are determined. It was established that the maximum amplitude of pressure oscillations is $15 \mathrm{MPa}$, the rise time of the pulse from zero to a maximum is $7-9 \mathrm{~s}$, and the fall time is $0.10-0.15 \mathrm{~s}$. The minimum pulse repetition period is $15-20 \mathrm{~s}$.

3. The operation of the vibrator systems in pulsed mode is characterized by hyperbolic dependence. With increasing pressure increases the force that creates a system of vibrators. The maximum force is $710 \mathrm{kN}$ for a system of two hydraulic rails at $P=13 \mathrm{MPa}$ and $600 \mathrm{kN}$ for a system of three hydraulic rails at $P=8 \mathrm{MPa}$.

\section{References}

1. Sofiyskiy, K.K., Zhitlenok, D.M., Petukh, A.P., Gavrilov, V.I., Zolotin, V.G., Kryshnev, A.S. (2014). Sposoby intensifikatsii degazatsii ugolnykh plastov $i$ predotvrashcheniya vybrosov uglya i gaza. Donetsk: Skhidniy vidavnichiy dim

2. Kryshnev, A.S. (2012). Rezultaty laboratornykh issledovaniy pri vozdeystvii na ugolnyy plast sistemoy gidravlicheskikh vibratorov cherez vmeshchayushchiye porody. Dnepropetrovsk: Geotekhnicheskaya mekhanika, (104), 18-23

3. Zhitlonok, D.M., Kryshnev, A.S., Petukh, A.P., Zolotin, V.G. (2012). Rezultaty eksperimentalnykh issledovaniy upravleniya sostoyaniyem gornogo massiva pri vibratsionnom vozdeystvii na ugolnyye plasty cherez vmeshchayushchiye porody. Dnepropetrovsk: Geotekhnicheskaya mekhanika, (101), 276-283

4. Zhitlonok, D.M., Kryshnev, A.S. (2012). Fizicheskaya sushchnost i matematicheskaya model upravleniya sostoyaniyem predelno-napryazhennogo gornogo massiva vibratsionnym vozdeystviyem na nego. Dnepropetrovsk: Geotekhnicheskaya mekhanika, (97), 145-151

5. Zhitlonok, D.M., Kryshnev, A.S., Vlasenko, V.V. (2012). Razrabotka sistem gidravlicheskikh vibratorov dlya vozdeystviya na ugolnyy plast cherez vmeshchayushchiye porody. Dnepropetrovsk: Geotekhnicheskaya mekhanika, (113), 113-122 